\title{
PARENTING A DEAF CHILD - HOW HEARING PARENTS COPE WITH THE STRESS OF HAVING DEAF CHILDREN
}

\author{
Joanna Kobosko
}

Institute of Physiology and Pathology of Hearing, Warsaw/Kajetany, Poland

Corresponding author: Joanna Kobosko, Institute of Physiology and Pathology of Hearing, Warsaw, Poland, e-mail: j.kobosko@ifps.org.pl

\begin{abstract}
Background: Parents of deaf or hard of hearing (D/HH) children experience greater parenting stress than parents of typically developing children. Studies of the stress experienced by these parents, and their methods of coping with it, give different results depending on the medical intervention used - cochlear implant or hearing aid - and in Poland such studies have not yet been done. This study addresses the ways by which parents handle the stress of adapting to their child's deafness. It asks whether their styles of coping with stressful situations - task oriented, emotion oriented or avoidance - change after diagnosis is made. Another issue was whether medical intervention, e.g. cochlear implantation in prelingually deaf children, relates to a certain style of coping with stress, and whether the parents' satisfaction with the decision to implant related to their behavior in stressful situations.
\end{abstract}

Material and methods: The research is based on a questionnaire containing demographic information about the parents (age, sex, education), their satisfaction with the decision on cochlear implantation, and information about the child. A Polish version of Coping Inventory for Stressful Situations (CISS) was used.

Results: The results show that mothers and fathers of $\mathrm{D} / \mathrm{HH}$ children differ in the intensity of their emotion-oriented and avoidance styles and that in stressful situations mothers use these styles significantly more often than fathers. Parents of $\mathrm{D} / \mathrm{HH}$ children using cochlear implants do not differ from those using hearing aids in terms of stress coping styles.

Conclusions: These insights offer practical suggestions of ways to psychologically help parents of deaf children, enabling them to cope better with their parenting a deaf child.

Key words: stress coping $\bullet$ deaf child $\bullet$ hearing parent $\bullet$ cochlear implant $\bullet$ hearing aid

\section{БЫТЬ РОДИТЕЛЕМ ГЛУХОГО РЕБЕНКА - КАК СЛЫШАЩИЕ РОДИТЕЛИ СПРАВЛЯЮТСЯ СО СТРЕССОМ, СВЯЗАННЫМ С ГЛУХОТОЙ ДЕТЕЙ}

\section{Резюме}

Введение: Родители глухих или слабослышащих детей испытывают бо́льший стресс, связанный с их воспитанием, чем родители типично развивающихся детей. Исследования, касающиеся стресса, испытываемого этими родителями, и способы их борьбы с ним, в случаях медицинского вмешательства (кохлеарный имплант по сравнению с использованием слухового аппарата), дают разные результаты. Раннее в Польше исследования такого рода не проводились. Исследование посвящено способам борьбы со стрессом родителей, приспосабливающихся к глухоте ребёнка. Вопрос в том, изменяются ли методы борьбы со стрессовыми ситуациями (стили: задания, эмоций или избегания) на разных этапах диагноза ребёнка. Другой вопрос, имеет ли медицинское вмешательство, например, кохлеарный имплант глухих детей до начала развития речи, связь со методом борьбы со стрессом и связано ли удовлетворение родителей решением о кохлеарном импланте с их поведением в стрессовых ситуациях.

Материалы и методы: Исследование основано на анкете, содержащей демографическую информацию о родителях (возраст, пол, образование), их удовлетворение решением о кохлеарном импланте и информацию о ребёнке. Была использована польская версия Coping Inventory for Stressful Situations (CISS) - Средства Борьбы со Стрессовыми Ситуациями.

Результаты: Результаты показывают что, во-первых, матери и отцы глухих и слабослышащих детей отличаются по интенсивности эмоционально ориентрованного стиля и стиля избегания и, во-вторых, в стрессовых ситуациях матери пользуются этими стилями значительно чаще чем отцы. Родители глухих и слабослышащих детей, использующих кохлеарные импланты, с точки зрения метода борьбы со стрессом не отличаются от родителей детей со слуховыми аппаратами. 
Вывод: Результаты исследования позволят найти практические решения, касающиеся психологической помощи для родителей глухих детей, чтобы дать им возможность лучше справиться с тем, что они родители глухого ребенка.

Ключевые слова: борьба со стрессом • глухой ребенок • слышащие родители • кохлеарный имплант • слуховой аппарат

\section{CRIANZA DE UN NIÑO SORDO - SUPERACIÓN DE ESTRÉS POR LOS PADRES QUE OYEN DE NIÑOS SORDOS}

\section{Extracto}

Introducción: Los padres de los niños sordos experimentan tensión de crianza de los hijos en un nivel más alto que los padres de los niños adecuado desarollados. Los estudios sobre la tensión experimentada por estos padres y sus métodos de enfrentarsela, en cuanto a la intervención médica (implantes cocleares comparando con la utilización del audífono), traen resultados diferentes. En Polonia tales estudios no han sido conducidos. El estudio es dedicado a los formas de la lucha contra el estrés de los padres que se adaptan a la sordera del niño. La pregunta es si los estilos de la lucha contra situaciones estresantes (los estilos de tarea, emoción y evitación) son modificados relativamente al tiempo del diagnóstico. Otra pregunta es si la intervención médica, por ejemplo la implantación coclear en niños prelingualmente sordos, está relacionada con el cierto estilo de la lucha contra el estrés, y si la satisfacción de los padres por la decisión sobre el implante coclear está relacionada con su comportamiento en situaciones estresantes.

Material y métodos: El estudio está basado en un cuestionario que contiene la información demográfica sobre padres (edad, sexo, educación), su satisfacción por la decisión sobre el implante coclear, e información sobre el niño. Fue usada la versión polaca del Coping Inventory for Stressful Situations (CISS) - Inventario de Adaptación en Situaciones Estresantes.

Resultados: Los resultados muestran que las madres y los padres de los niños sordos se diferencian en la intensidad de los estilos de emoción y evitación y que en situaciones estresantes las madres usan estos estilos considerablemente más frequente que los padres. Los padres de niños sordos que usan implantes cocleares (contra los que usan los audífonos) no son diferentes en terminus de los estilos de la lucha con estreso.

Conclusión: Los resultados ayudarán encontrar los soluciones practicos acerca de la ayuda psicológica a los padres de niños sordos, para permitirles adaptarse mejor por elsentido de que son los padres de un niño sordo.

Palabras claves: la lucha con estreso $\bullet$ niño sordo $\bullet$ padre que oye $\bullet$ implante coclear $\bullet$ audífono

\section{Background}

Becoming a parent of a deaf, or hard-of-hearing child (D/ $\mathrm{HH}$ ) is accompanied by stresses of various intensity. Mothers and fathers experience psychological distress related with their child's deafness and its implications for the life of the child and the entire family [1-6]. The parenting stress has been investigated in many studies. However, the results concerning the general parenting stress are ambiguous and indicate either that its intensity is similar to that in the general population of hearing children's parents $[5,7,8]$, or indicate a heightened level, particularly in domains related to the child's deafness, such as: communication, education, emotional well being, equipment, financial, healthcare, social support $[5,9]$. The parenting stress grows as the child with a hearing loss gets older [10]. The research by Horsch et al. [11] indicates that parents of children using cochlear implants (CIs) experience stress of an intensity comparable to that of parents of a hearing child, and that the stress intensity is heightened in parents of $\mathrm{D} / \mathrm{HH}$ children without CIs. So far there has been no research on the styles of stress coping adopted by parents of $\mathrm{D} / \mathrm{HH}$ children, whether these styles are modified relative to the child's age and the passage of time from the diagnosis of deafness, and if the mothers and the fathers of $\mathrm{D} / \mathrm{HH}$ children adopt different, or similar styles of stress coping.

Endler and Parker [12,13] identify three styles of stress coping: 1/ Task-oriented style - characterizing people who undertake efforts aimed at problem solving, 2/ Emotion-oriented style - characterizing people who focus on their own feelings and emotions, 3/ Avoidance style - characterizing people who tend to avoid thinking of or experiencing stressful situations, either in the form of attention-diverting activities (e.g. watching TV), or making extensive social contacts.

\section{Aim of the study}

The goal of the present study was to explore the following questions:

- Coping styles of hearing parents (mothers vs. fathers) in adapting to their child's deafness.

- Parents' coping styles and the time since diagnosis of deafness in their child.

- Parents' coping styles and type of medical intervention (cochlear implant $v s$. conventional hearing aid).

- Satisfaction of the parents of CI children with the decision about the implant for their child and their coping styles. 
Table 1. Socio-demographic data of parents of $\mathrm{D} / \mathrm{HH}$ children and their children.

\begin{tabular}{|c|c|}
\hline $\begin{array}{l}\text { Parents } \\
\text { All parents } \\
\text { Mothers } \\
\text { Fathers } \\
\text { Missing data }\end{array}$ & $\begin{array}{l}N=93(100 \%) \\
N=73(78.5 \%) \\
N=19(20.4 \%) \\
1(1.1 \%)\end{array}$ \\
\hline $\begin{array}{l}\text { Education } \\
\text { Elementary school } \\
\text { High school / } \\
\text { Vocational high school } \\
\text { Incomplete higher education } \\
\text { University (higher education) } \\
\text { Missing data }\end{array}$ & $\begin{array}{l}N=5(5.4 \%) \\
N=33(35.5 \%) \\
N=12(12.9 \%) \\
N=42(45.2 \%) \\
1(1.1 \%)\end{array}$ \\
\hline $\begin{array}{l}\text { Marital status } \\
\text { Married } \\
\text { Other (divorced, single, } \\
\text { widowed) } \\
\text { Missing data }\end{array}$ & $\begin{array}{l}N=64(68.8 \%) \\
N=6(6.5 \%) \\
N=23(24.7 \%)\end{array}$ \\
\hline $\begin{array}{l}\text { Number of children } \\
\text { One child } \\
\text { More than one } \\
\text { Missing data }\end{array}$ & $\begin{array}{l}N=35(37.6 \%) \\
N=57(62.4 \%) \\
1(1.1 \%)\end{array}$ \\
\hline $\begin{array}{l}\text { Parent's age in years } \\
\text { All parents } \\
\text { Mothers } \\
\text { Fathers }\end{array}$ & $\begin{array}{c}\mathbf{M}(\mathbf{S D}) \\
33.93(4.35) \\
33.44(4.32) \\
35.89(4.01)\end{array}$ \\
\hline $\begin{array}{l}\text { Parent satisfaction with } \mathrm{Cl} \text { (1 } \\
\text { All parents }\end{array}$ & $\begin{array}{l}0 \text { points) } \\
M=9.55(S D=1.29)\end{array}$ \\
\hline $\begin{array}{l}\text { Children } \\
\text { Girls } 38 \\
\text { Boys } 46 \\
\text { Missing data }\end{array}$ & $\begin{array}{l}\mathbf{N}=\mathbf{8 8}(\mathbf{1 0 0} \%) \\
(43.2 \%) \\
(52.3 \%) \\
4(4.5 \%)\end{array}$ \\
\hline $\begin{array}{l}\text { Degree of hearing loss } \\
20-39 \mathrm{~dB} \\
40-69 \mathrm{~dB} \\
70-89 \mathrm{~dB} \\
90-120 \mathrm{~dB} \\
>120 \mathrm{~dB}\end{array}$ & $\begin{array}{l}3(3.4 \%) \\
7(8.0 \%) \\
12(13.8 \%) \\
49(55.7 \%) \\
14(15.9 \%)\end{array}$ \\
\hline $\begin{array}{l}\text { Type of device used } \\
\text { Cochlear implant }(\mathrm{Cl}) \\
\text { Hearing aid }(\mathrm{HA}) \\
\text { Missing data }\end{array}$ & $\begin{array}{l}74(84.1 \%) \\
13(14.8 \%) \\
1(1.1 \%)\end{array}$ \\
\hline $\begin{array}{l}\text { Child's age in months } \\
\text { All children } \\
\text { Child's age at the diagnosis } \\
\text { of hearing loss } \\
\text { Child's age at Cl implantation }\end{array}$ & $\begin{array}{cc}\mathbf{M} & \mathbf{( S D )} \\
55.82 & (28.38)\end{array}$ \\
\hline
\end{tabular}

\section{Material and methods}

Participants

Table 1 shows the distribution of socio-demographic variables of the studied sample of hearing parents of $\mathrm{D} / \mathrm{HH}$ children and their children.

\section{Instruments}

Questionnaire on the socio-demographic data was applied to collect information about parents and their $\mathrm{D} / \mathrm{HH}$ children such as: age, gender, education, marital status, children's type of device used, age of diagnosis of hearing loss, hearing level etc. (Table 1).
Table 2. Coping with stressful situation (CISS) - mean $(M)$, standard deviation (SD) and Polish norms (in stens) - parents of $\mathrm{D} / \mathrm{HH}$ children.

\begin{tabular}{|c|c|c|}
\hline CISS & M (SD) & $\begin{array}{c}\text { Polish norms } \\
\text { (in stens) }\end{array}$ \\
\hline $\begin{array}{c}\text { Task-Oriented } \\
\text { Style (TOS) }\end{array}$ & $58.32(8.49)$ & 6.0 \\
\hline $\begin{array}{c}\text { Emotion-Oriented } \\
\text { Style (EOS) }\end{array}$ & $40.97(9.94)$ & 5.25 \\
\hline $\begin{array}{c}\text { Avoidance Style } \\
\text { (AS) }\end{array}$ & $40.35(7.87)$ & 5.33 \\
\hline $\begin{array}{c}\text { Distraction Style } \\
\text { (DS) }\end{array}$ & $17.27(4.8)$ & 5.3 \\
\hline $\begin{array}{c}\text { Social Diversion } \\
\text { Style (SDS) }\end{array}$ & $16.25(4.07)$ & 5.8 \\
\hline
\end{tabular}

Coping Inventory for Stressful Situations (CISS) by Endler \& Parker [12] designed to assess the general style of coping with stressful situations in three scales: the Task-Oriented Scale (TOS), the Emotion-Oriented Scale (EOS) and the Avoidance Scale (AS). The Avoidance scale is further divided into two subscales: the Distraction Scale (DS) and the Social Diversion Scale (SDS). Responses are marked on the 5-point scale, and scores for each question are summarized to obtain a score for each subscale, which may range from 16 to 80 .

\section{Results}

Coping styles of hearing parents of $\mathrm{D} / \mathrm{HH}$ children and Polish norms in the general population

Parents of $\mathrm{D} / \mathrm{HH}$ children prefer a style of coping with stress of average intensity (5-6 sten) -Table 2.

Coping styles of mothers in comparison with fathers of $\mathrm{D} / \mathrm{HH}$ children

The mothers of $\mathrm{D} / \mathrm{HH}$ children, significantly more often than fathers, use in stressful situations the emotion-focused style (EOS - T-Student test: $\mathrm{t}(90)=3.63 ; \mathrm{p}=0.000)$, which is in line with the Polish norms for women and men. Also, these mothers, with significantly greater frequency, prefer an avoidance style (AS - T-Student test: $\mathrm{t}(90)=2.52$; $\mathrm{p}=0.013$ ) in both its sub-variants: Distraction (DS - T-Student test: $\mathrm{t}(90)=1.94 ; \mathrm{p}=0.05)$ and Social Diversion (SDS T-Student test: $\mathrm{t}(90)=2.55 ; \mathrm{p}=0.013)$ - Figure 1 .

Coping styles of hearing parents of $\mathrm{D} / \mathrm{HH}$ children: cochlear implant users and hearing aid users

The parents of $\mathrm{D} / \mathrm{HH}$ children - CI or HA users - adopt similar styles of coping with stressful situations. There are no statistically significant differences between these two groups.

Coping styles of hearing parents of $\mathrm{D} / \mathrm{HH}$ children and duration since diagnosis of child's deafness

The parents of $\mathrm{D} / \mathrm{HH}$ children adopt different coping styles depending on the time since diagnosis of deafness, in terms of the avoidance style (AS - Kruskal-Wallis test: $\chi^{2}(2)=5.76$; 


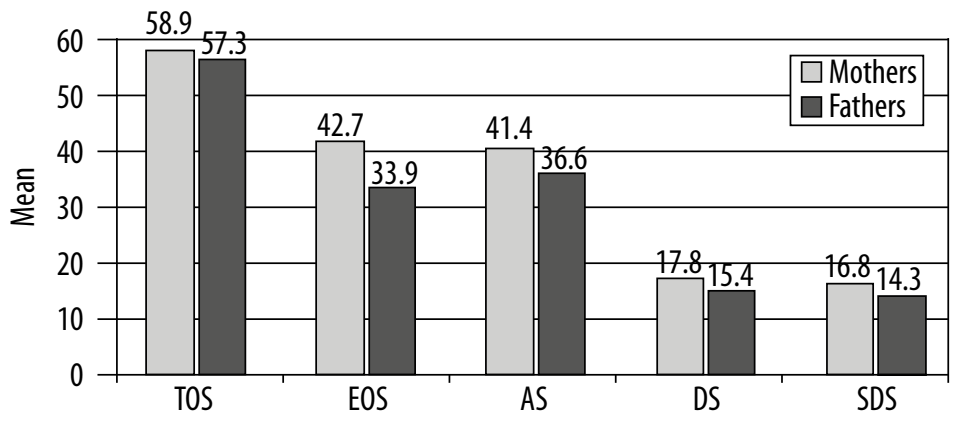

Figure 1. Coping styles (CISS) in mothers and fathers of $\mathrm{D} / \mathrm{HH}$ children (means).

Table 3. Avoidance Scale (AS) and Social Diversion Scale (SDS) scores (means) in 3 groups of parents of children diagnosed with hearing loss <24 months, between 24-60 months, and >60 months earlier.

\begin{tabular}{|c|c|c|c|c|c|c|}
\hline \multicolumn{2}{|c|}{ Duration since diagnosis of hearing loss } & \multirow{2}{*}{$\begin{array}{l}\mathbf{N} \\
21 \\
\end{array}$} & \multirow{2}{*}{$\begin{array}{c}\text { Min } \\
27.00\end{array}$} & \multirow{2}{*}{$\begin{array}{r}\text { Max } \\
51.00\end{array}$} & \multirow{2}{*}{$\begin{array}{l}\text { Mean } \\
38.48\end{array}$} & \multirow{2}{*}{$\begin{array}{l}\text { SD } \\
6.24 \\
\end{array}$} \\
\hline & Avoidance Style & & & & & \\
\hline \multirow[t]{2}{*}{$<24$ months } & Social Diversion Style & 21 & 7.00 & 23.00 & 15.00 & 3.97 \\
\hline & Valid N (listwise) & 21 & & & & \\
\hline \multirow{3}{*}{$24-60$ months } & Avoidance Style & 39 & 19.00 & 59.00 & 39.56 & 7.52 \\
\hline & Social Diversion Style & 39 & 5.00 & 22.00 & 15.82 & 4.12 \\
\hline & Valid N (listwise) & 39 & & & & \\
\hline \multirow[t]{3}{*}{$>60$ months } & Avoidance Style & 25 & 26.00 & 56.00 & 43.36 & 8.38 \\
\hline & Social Diversion Style & 25 & 10.00 & 24.00 & 17.92 & 3.76 \\
\hline & Valid N (listwise) & 25 & & & & \\
\hline
\end{tabular}

$\mathrm{p}=0.05)$ and its variety - the social diversion style (SDS Kruskal-Wallis test: $\left.\chi^{2}(2)=7.26 ; \mathrm{p}<0.05\right)$. The group of parents of children diagnosed more than 60 months earlier is marked by the significantly more frequent presence of the AS (MannWhitney $U$ test $-U=166 ; \mathrm{p}<0.05$ ) and SDS (Mann-Whitney $\mathrm{U}$ test $-\mathrm{U}=153.5 ; \mathrm{p}<0.05)$ styles as compared with the group of parents whose children have been diagnosed less than 24 months earlier, and that in the range of 24-60 months - Table 3 . We noticed a weak positive correlation between the time from the moment of diagnosis and the adoption of the avoidance style by the parents (AS $-\mathrm{r}=0.25$; $\mathrm{p}=0.019$ ), including the social diversion style ( $S D S-r=0.23$; $\mathrm{p}=0.035$ ).

Parents' satisfaction with the decision about cochlear implantation and coping styles

As shown in the graph below (Figure 2) the variable 'satisfaction with the decision about CI' does not differentiate the parents of $\mathrm{D} / \mathrm{HH}$ children - other than maximum (10 points) grade of the satisfaction was indicated by only $21.3 \%$ parents, all others declared the maximum satisfaction. This result makes it impossible to conduct a statistical verification of the relation between the satisfaction of the parents of the CI child and the styles of coping in stressful situations they adopt.

\section{Discussion}

Presented results show the significance of avoidance style in coping with stress, especially by the mothers of deaf children. The avoidance style, with its variety, i.e. seeking out social

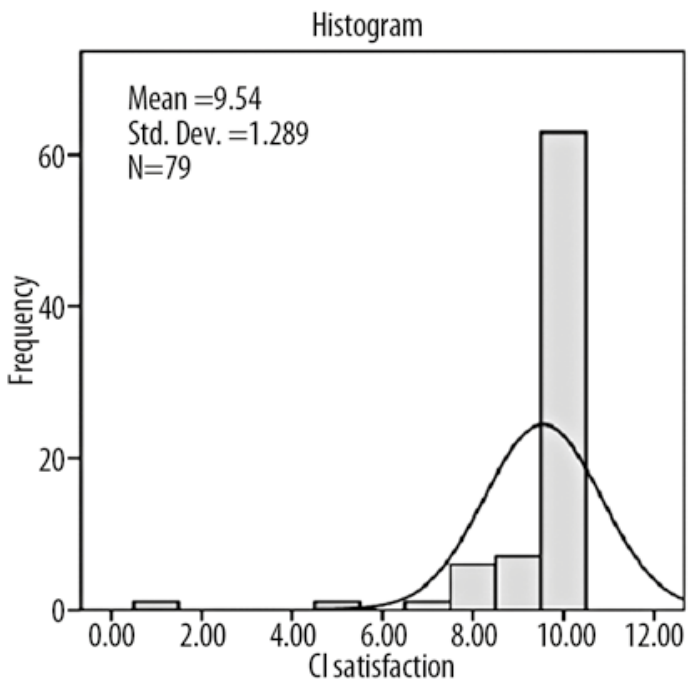

Figure 2. Distribution of satisfaction with the decision about $\mathrm{Cl}$ in parents of implanted children.

contacts, correlates positively, albeit weakly, with the time since diagnosis of their child's deafness. What is interesting is that the avoidance style is positively correlated with the experience of social anxiety by parents of mentally handicapped children [14]. As far as parents of deaf children are concerned, we may expect a similar relation: they experience social anxiety and at the same time seek out social contacts, possibly trying in this way to cope with the stress they experience. 
The importance of avoidance style has also been found in parents of children with mental deficiencies [15], such as autism [16], or mothers of children with cerebral palsy, who more often avoid confront their stress by becoming engaged in replacement activities [17]. This avoidance style is characteristic of mothers, not fathers, which leads to the conclusion that research on styles of coping with stress related to a child's handicap should definitely take into account the parent's gender (although fathers are still less accessible!), especially if we want to investigate the dynamics of how parents adapt to their child's deafness.

The kind of medical intervention - cochlear implantation $v s$. conventional hearing aid - proves to have no relevance for coping styles preferred by parents. The kind of medical intervention has been a criterion in many stress coping studies $[4,11]$. It should be noted that the construct of 'parent's satisfaction with the implantation decision' has proven not to be a factor differentiating parents, which suggests that parent's satisfaction with the implant may be due to many causes and does not have to co-exist with the child's effective rehabilitation.

\section{Conclusions}

- The parents of deaf and hard of hearing $(\mathrm{D} / \mathrm{HH})$ children adopt different styles of coping in stressful situations
- task-oriented, emotion-oriented and avoidance - of an average intensity $(5,6$ sten) which accords with Polish norms for the general population.

- Mothers and fathers of $\mathrm{D} / \mathrm{HH}$ children differ in the intensity of their emotion-oriented and avoidance styles. In stressful situations mothers use those styles significantly more often - in relation to the emotion-focused style it corresponds with the gender-related proportions observed in the general population. The more frequent adoption of the avoidance style by mothers than by fathers of $\mathrm{D} / \mathrm{HH}$ children is related to the child's deafness.

- The parents of D/HH children using cochlear implants, $v s$. those using the hearing aids, are no different in terms of stress coping styles.

- The time since diagnosis of deafness in a child is positively weakly correlated with the intensity of the avoidance style, including the social diversion style, in parents.

- Long lasting and growing with the passage of time from the diagnosis, domination of the avoidance style indicates the difficulties parents have in adapting to their child's deafness and the negative emotions which they do not confront. On the other hand, greater intensity of the social diversion style may also be adaptive, e.g. it creates opportunities to receive support.

- Parents of D/HH children need various forms of psychological help in order to cope effectively with the stress of having a deaf child [14].

\section{References:}

1. Meadow-Orlans KP: Sources of stress for mothers and fathers of deaf and hard of hearing children. Am Ann Deaf, 1995; 140(4): 352-57

2. Quittner AL, Steck JT, Rouiller RL: Cochlear implants in children. A study of parental stress and adjustment. Am J Otol, 1991; 12 (Suppl.): 95-104

3. Zalewska M: Psychologiczne aspekty stwierdzenia głuchoty u dziecka. [Psychological aspects of deafness diagnosis in children]. In: Rola J (ed.), Wybrane problemy psychologicznej diagnozy zaburzen rozwoju dzieci. Warsaw: Wydawnictwo WSPS; 1998, 177-86

4. Spahn C, Richter B, Burger T et al: A comparison between parents of children with cochlear implants and parents of children with hearing aids regarding parental distress and treatment expectations. Int J Pediatr Otorhinolaryngol, 2003; 67: 947-55

5. Quittner AL, Barker DH, Cruz I, Snell C, Grimley ME, Botteri $\mathrm{M}$ : Parenting stress among parents of deaf and hearing children. Associations with language delays and behavior problems. Parenting. Science and Practice, 2010; 10: 136-55

6. Kobosko J, Zalewska M: Maternal identity of hearing mothers of deaf adolescents. Empirical studies - an interpersonal approach. The Volta Review, 2011; 111(1): 39-59

7. Meadow-Orlans KP: Stress, support, and deafness. Perceptions of infants' mothers and fathers. JEI, 1994; 18(1): 91-102

8. Pip-Siegel S, Sedey AL, Yoshinaga-Itano C: Predictors of parental stress in mothers of young children with hearing loss. J Deaf Stud Deaf Educ, 2002; 7(1): 1-17

9. Meinzen-Derr J, Lim LH Y, Choo DI et al: Pediatric hearing impairment caregiver experience. Impact of duration of hearing loss on parental stress. Int J Pediatr Othorinolaryngol, 2008; 72: $1693-703$
10. Konstantareas M, Lampropoulou M: Stress in Greek mothers with deaf children. Effects of child characteristics, family resources and cognitive set. Am Ann Deaf, 1995; 140(3): 264-70

11. Horsch U, Weber C, Bertram B, Detrois P: Stress experienced by parents of children with cochlear implants compared with parents of deaf children and hearing children. Am J Otol, 1997; 18: $161-65$

12. Endler NS, Parker JDA: Multidimensional assessment of coping. A critical evaluation. J Pers Soc Psychol, 1990; 58: 844-54

13. Endler NS, Parker JDA: Assessment of multidimensional coping: task, emotion and avoidance strategies. Psychological Assessment, 1994; 6: 50-60

14. Maslowiecka A: Radzenie sobie ze stresem przez matki dzieci $\mathrm{z}$ uposledzeniem umyslowym. Psychologia Rozwojowa, 2006; 11(1): 119-30

15. Margalit M, Raviv A, Ankonina D: Coping and coherence among parents with disabled children. Journal of Clinical Child Psychology, 1992; 2(3): 202-9

16. Pisula E, Kossakowska Z: Sense of coherence and coping with stress among mothers and fathers of children with autism. J Autism Dev Disord, 2010; 40: 1485-94

17. Parchomiuk M: Rodzice dzieci z mozgowym porazeniem dzieciecym wobec sytuacji trudnych. Lublin: UMCS

18. Kobosko J: Pomoc psychologiczna słyszacym rodzicom a efektywnosc rehabilitacji dziecka gluchego [Psychological assistance for the hearing parents and rehabilitation efficacy within deaf children]. Otorhinolaryngology, 2011; 10(1): 8-14 